ORIGINAL PAPER

\title{
Prognostic VAlue of P53 Protein EXPRession in Giant
}

CELL TUMOR OF BONE

Ulviye Yalcinkaya $^{1}$, Nesrin Ugras ${ }^{1}$, Selva Kabul ${ }^{1}$, Gokhan Ocakoglu ${ }^{2}$, Muhammed S. Bilgen ${ }^{3}$

${ }^{1}$ Department of Surgical Pathology, Uludag University Medical School, Bursa, Turkey

${ }^{2}$ Department of Oncology and Pediatric Biostatistics, Uludag University Medical School, Bursa, Turkey

${ }^{3}$ Department of Orthopedics, Uludag University Medical School, Bursa, Turkey

\begin{abstract}
Giant cell tumor of bone (GCTB) is a benign tumor with a tendency for local recurrence. GCTB may cause lung metastases, and secondary malignant GCTB is rare. Its histological appearance does not predict local aggressiveness and/or the metastatic potential of the tumor. We aimed to investigate the prognostic value of the Ki-67 proliferative index and $\mathrm{p} 53$ protein expression in GCTB in predicting local recurrence, lung metastasis, and malignant transformation. We retrospectively reviewed 42 cases of GCTB. The p 53 expression was positive in 20 cases. We used $10 \%$ as a cut-off value for $\mathrm{p} 53$ expression. In 10 cases, there were local recurrences. Lung metastases were found in three cases and malignant transformation was found in one case with classical GCTB located in the sacrum three years following diagnosis. The Ki-67 index was higher in cases with recurrence, but this difference was not statistically significant. Of the recurrent cases, two had no p53 staining while eight had moderate-to-strong staining. The staining was usually weakly positive in the non-recurrent cases. In conclusion, we believe that p53 may be used as a marker for the biological behavior of GCTB.
\end{abstract}

Key words: giant cell tumor of bone, recurrence, Ki-67, p53.

\section{Introduction}

Giant cell tumor of bone (GCTB) is a benign bone tumor with a tendency for local aggressiveness. It was initially described by Jaffe et al. in 1940 [1, 2, $3]$. It comprises $5 \%$ of all bone tumors. Predilection sites are around the knee joint and epiphyses of long bones. There is a slight predominance of male patients in the Asian countries and female patients in Western countries, and some reports have suggested that there is no difference at all $[4,5,6,7,8]$. There is a peak of incidence in the $3^{\text {rd }}$ and $4^{\text {th }}$ decades $[1,2]$.

Curettage is preferred in therapy over total excision, because the latter may result in a loss of function depending on the tumor site. Recurrence, however, is frequent following curettage and incomplete resection and is rare following wide resection. The recurrence rate within the first couple of years is approximately $25 \%[2,4,9]$.

Although histologically benign, GCTB may cause lung metastases in $2-3 \%$ of cases in the 3-4 years following diagnosis $[2,4,10,11]$. Malignant transformation of GCTB is rare, i.e. less than $2 \%$, and is usually found in cases with multiple local recurrences. Most of malignant GCTB develop either de novo or years after surgical therapy accompanied by radiotherapy $[12,13]$.

Histologically, the tumor consists of multiple multinucleated giant cells with a background of oval to round, spindle-like mononuclear cells $[1,5,14]$. This histological appearance does not predict local aggressiveness and/or metastatic potential of the tumor. Recently, the proliferation marker Ki-67 and a wellknown tumor suppressing gene, p53, are frequently used as prognostic factors in most of the tumors. We 
aimed to investigate the prognostic value of the $\mathrm{Ki}-67$ proliferative index and $\mathrm{p} 53$ protein expression in GCTB in predicting local recurrence, lung metastasis, and malignant transformation.

\section{Material and methods}

This was a retrospective case-control study. Of the cases referred to the Surgical Pathology Department of Uludag University, School of Medicine between

Table I. Clinicopathological findings of cases $(n=42)$

\begin{tabular}{|c|c|c|}
\hline VARIABLE & & No. OF CASES $(\%)$ \\
\hline \multirow[t]{2}{*}{ Gender } & Female & $22(52)$ \\
\hline & Male & $20(48)$ \\
\hline \multirow[t]{3}{*}{ Age (years) } & $\leq 20$ & 4 \\
\hline & $20-40$ & 27 \\
\hline & $\geq 40$ & 11 \\
\hline \multirow[t]{11}{*}{ Tumor site } & Distal femur & $8(19)$ \\
\hline & Proximal tibia & $8(19)$ \\
\hline & Vertebra & $5(12)$ \\
\hline & Proximal femur & $4(10)$ \\
\hline & Sacrum & $3(7)$ \\
\hline & Proximal fibula & $3(7)$ \\
\hline & Distal ulna & $2(5)$ \\
\hline & Distal radius & $2(5)$ \\
\hline & Distal tibia & $2(5)$ \\
\hline & Phalanx & $2(5)$ \\
\hline & Others & $3(7)$ \\
\hline \multirow{2}{*}{$\begin{array}{l}\text { Secondary aneu- } \\
\text { rysmal bone cyst }\end{array}$} & Yes & $12(29)$ \\
\hline & No & $30(71)$ \\
\hline \multirow[t]{2}{*}{ Vascular invasion } & Yes & $4(9)$ \\
\hline & No & $38(91)$ \\
\hline \multirow{2}{*}{$\begin{array}{l}\text { Pathological } \\
\text { fracture }\end{array}$} & Yes & $2(5)$ \\
\hline & No & $40(95)$ \\
\hline \multirow{2}{*}{$\begin{array}{l}\text { Onset of lung } \\
\text { metastases }\end{array}$} & Yes & $3(7)$ \\
\hline & No & $39(93)$ \\
\hline \multirow[t]{2}{*}{ Surgery } & Curettage & $27(64)$ \\
\hline & Resection & $15(36)$ \\
\hline \multirow[t]{2}{*}{ Recurrence } & Yes & $10(24)$ \\
\hline & No & $32(76)$ \\
\hline \multirow[t]{3}{*}{ Current status } & Dead & $2(5)$ \\
\hline & Alive & $32(76)$ \\
\hline & NA & $8(19)$ \\
\hline $\begin{array}{l}\text { Median follow-up, } \\
\text { months }\end{array}$ & & $\begin{array}{c}34 \\
\text { (range 1-162) }\end{array}$ \\
\hline
\end{tabular}

NA-not available
2002 and 2013, 42 cases of GCTB were included in the study. Hematoxylin-eosin tissue sections of the resected tumor tissues were re-evaluated. The paraffin blocks best representing the tumor were selected for immunohistochemical staining. Follow-up information was obtained from hospital files and/or by contacting with the patients. Data on age, gender, tumor site, surgical procedure, pathological fractures, local recurrence, lung metastasis, malignant transformation, lymphovascular invasion, and secondary aneurysmal bone cyst presence were noted. The potential relationship between the clinical and pathological findings and $\mathrm{Ki}-67$ proliferation index and $\mathrm{p} 53$ protein expression were evaluated.

\section{Immunohistochemical staining}

Immunohistochemical staining was performed with the Leica Bond-Max automatic immunohistochemical stain device using Ki-67 (clone MIB-1, dilution $1: 200$, Dako, Tokyo, Japan), and p53 (clone DO-7, dilution $1: 500$, Dako, Tokyo, Japan) antibodies with the polymer DAB kit. As positive controls, colon adenocarcinoma was used for p53, and tonsil was used for Ki-67. No negative control was used in the study.

\section{Microscopic evaluation}

The Ki-67 proliferative index was scored semiquantitatively as low $(+)$, intermediate $(++)$, or high $(+++)$, depending on the number of positive mononuclear cells in the most prominently stained area, using a $\times 40$ lens, setting up threshold values as $<5 \%, 5-20 \%$ and $>20 \%$, respectively.

Immunostaining for $\mathrm{p} 53$ protein was evaluated using $\times 40$ magnification light microscopy. These results were categorized as negative or positive, according to a cut-off value of $10 \%$ to discriminate between negative and positive cases.

\section{Statistical analysis}

Statistical analyses were performed using the SPSS v20 software program (SPSS, Chicago, IL, USA). Data were expressed as the median value (minimum-maximum) and percentages for frequencies. For comparison between groups, the Mann-Whitney $\mathrm{U}$ and Fisher's exact tests were used where appropriate. A p value less than 0.05 was considered significant.

\section{Results}

There were 22 female (52.4\%) and 20 male (47.6\%) patients with a median age of 31.5 years (15-75 years). All clinical data are listed in Table I. Most of the tumors were located in the distal femur and proximal tibia of the knee region (38.8\%, Fig. 1). Surgical therapy consisted of curettage in 27 cases and resection in 15 cases. 

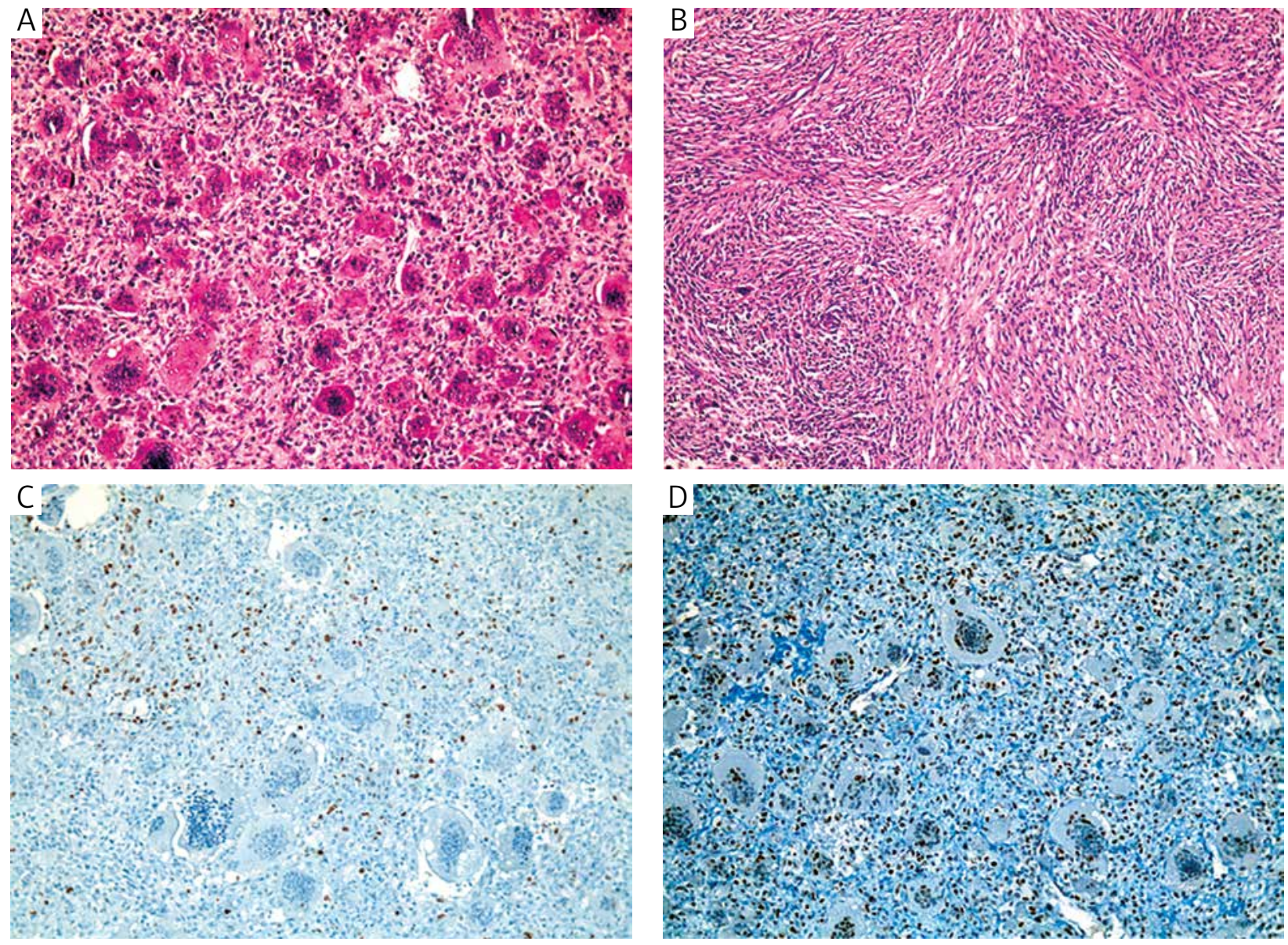

Fig. 1. A) Giant cell tumor in the distal femur in a 31-year-old woman. Multinucleated giant cells uniformly distributed among mononuclear stromal cells. B) Spindle cell proliferation with a storiform pattern associated with foamy cells (hematoxylin-eosin, $\times 200)$. C) $\mathrm{Ki}-67$ index was moderate $(=10 \%, \mathrm{Ki}-67,200 \times)$. D) Nuclear positivity for p53 in both stromal and giant cells $(\mathrm{p} 53,200 \times)$

\section{Recurrence}

In 10 cases, there were local recurrences $(23.8 \%)$. The clinical findings in the recurrent cases are listed in Table II. The initial surgical procedure in recurrent cases was curettage in seven cases and wide resection in three cases.

The recurrence rate was $26.92 \%(7 / 26)$ in the curettage cases and $18.75 \%(3 / 16)$ in the resection cases. Statistical analysis revealed no significant association between recurrence and the type of surgery $(\mathrm{p}=$ $=0.490$ ). Recurrences in the resection cases were most likely due to unsuccessful surgery because of the complicated tumor site, i.e. vertebrae. In recurrent cases, three had multiple recurrences. One case had two and the other two cases had four recurrences. The patient with the tumor located in the clivus had undergone operations twice and received radiotherapy as the resection was incomplete. The residual tumor was under control and the patient did not have any complaints.

The patient with a tumor located in the distal tibia had four recurrences in the past decade (Fig. 2). She was treated with curettage every time. She received radiotherapy and hyperbaric oxygen therapy following the last operation. She has been in follow-up for four years without recurrence. The patient with a tumor located in the proximal femur underwent prosthesis implantation following the $4^{\text {th }}$ recurrence. One year after the implantation, the patient is well and has no complaints.

\section{Lung metastases}

Lung metastases were found in three cases $(7.14 \%)$. Two of the patients were female and one patient was male. In cases with tumors in the vertebra and proximal tibia, the metastases were found at the time of diagnosis. In the case with the tumor in the thoracic vertebra, the metastasis was found at the time of recurrence. One of the patients had dropped out of the follow-up evaluation, while one patient received denosumab, a novel RANKL inhibitor (receptor activator of nuclear factor $\kappa-\mathrm{B}(\mathrm{NF}-\kappa \mathrm{B})$ ligand), and the other patient received bisphosphonate. Both are still under treatment. 
Table II. Clinical data of recurrent giant cell tumor cases

\begin{tabular}{|c|c|c|c|c|c|c|c|c|}
\hline Case & AGE & SEX & Site & $\begin{array}{l}\text { FIRST SURGICAL } \\
\text { PROCEDURE }\end{array}$ & $\begin{array}{l}\text { NuMBER OF } \\
\text { RECURRENCES }\end{array}$ & $\begin{array}{l}\text { TIME TO FIRST } \\
\text { RECURRENCE }\end{array}$ & $\begin{array}{l}\text { FINAL SURGICAL } \\
\text { PROCEDURE }\end{array}$ & $\begin{array}{l}\text { POSTRECURRENT } \\
\text { FOLLOW-UP } \\
\text { (MONTHS) }\end{array}$ \\
\hline 1 & 56 & $\mathrm{~F}$ & $\begin{array}{l}\text { vertebra } \\
\text { (C3) }\end{array}$ & resection & 1 & 12 months & wide resection & 96 \\
\hline 2 & 37 & $\mathrm{~F}$ & $\begin{array}{l}\text { proximal } \\
\text { femur }\end{array}$ & curettage & 4 & 5 months & $\begin{array}{l}\text { prothesis } \\
\text { replacement }\end{array}$ & 12 \\
\hline 3 & 23 & $\mathrm{~F}$ & $\begin{array}{l}\text { proximal } \\
\text { tibia }\end{array}$ & curettage & 1 & 28 months & $\begin{array}{l}\text { curettage and bone } \\
\text { grafting }\end{array}$ & 35 \\
\hline 4 & 34 & $\mathrm{~F}$ & $\begin{array}{l}\text { distal } \\
\text { tibia }\end{array}$ & curettage & 4 & 30 months & $\begin{array}{l}\text { curettage and bone } \\
\text { grafting } \\
\text {-radiotherapy }\end{array}$ & 40 \\
\hline 5 & 34 & $\mathrm{M}$ & clivus & curettage & 2 & 5 months & $\begin{array}{l}\text { wide resection } \\
\text {-radiotherapy }\end{array}$ & 29 \\
\hline 6 & 23 & $\mathrm{~F}$ & $\begin{array}{c}\text { vertebra } \\
\text { (Th11) }\end{array}$ & resection & 1 & 15 months & wide resection & 12 \\
\hline 7 & 27 & M & $\begin{array}{l}\text { vertebra } \\
(\mathrm{Th} 7)\end{array}$ & resection & 1 & 5 months & wide resection & 13 \\
\hline 8 & 38 & M & phalanx & curettage & 1 & 15 months & amputation & 2 \\
\hline 9 & 25 & $\mathrm{~F}$ & $\begin{array}{l}\text { proximal } \\
\text { tibia }\end{array}$ & curettage & 1 & 9 months & $\begin{array}{l}\text { curettage and bone } \\
\text { cementing }\end{array}$ & 4 \\
\hline 10 & 17 & $\mathrm{~F}$ & phalanx & curettage & 1 & 3 months & $\begin{array}{l}\text { curettage and bone } \\
\text { grafting }\end{array}$ & 5 \\
\hline
\end{tabular}
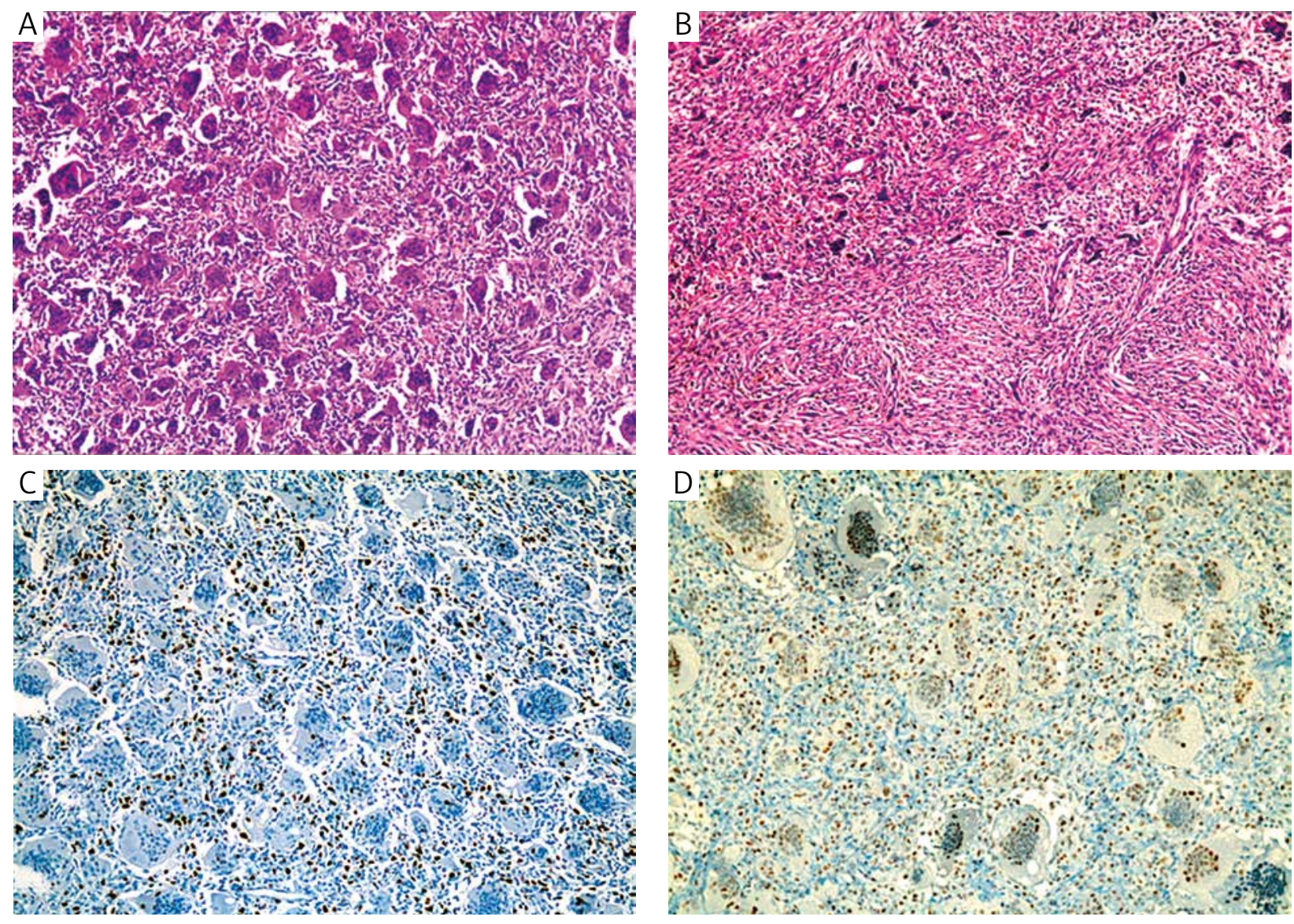

Fig. 2. A) Recurrent giant cell tumor in the distal tibia in 34-year-old woman. B) Histological features typical of a giant cell tumor merge into an area predominantly consisting of spindle cells $(\mathrm{HE}, \times 200)$. C) Ki-67 index was high $(=35 \%)$ in the stromal cells $(\mathrm{Ki}-67,200 \times)$. D) Overexpression of nuclear p53 is evident in the recurrent tumor $(\mathrm{p} 53,200 \times)$ 


\section{Vascular invasion}

Vascular invasion was found in four cases $(9.52 \%)$ The only recurrence in this group of cases was found in the case with the tumor in the distal tibia. The vascular invasion had no relationship with lung metastases.

\section{Aneurysmal bone cysts and pathological fractures}

In 12 cases $(28.57 \%)$, we found secondary aneurysmal bone cysts. Pathological fractures were present in two cases $(4.76 \%)$ with tumors in the distal femur and carpal bones.

A malignant transformation was found in one case $(2.38 \%)$ with classical GCTB located in the sacrum three years following diagnosis (Fig. 3). The patient did not receive radiotherapy following initial treatment, and the transformation was into osteosarcoma. The patient underwent wide resection followed with chemotherapy. Unfortunately, the patient died seven months later with local recurrences and lung metastases.
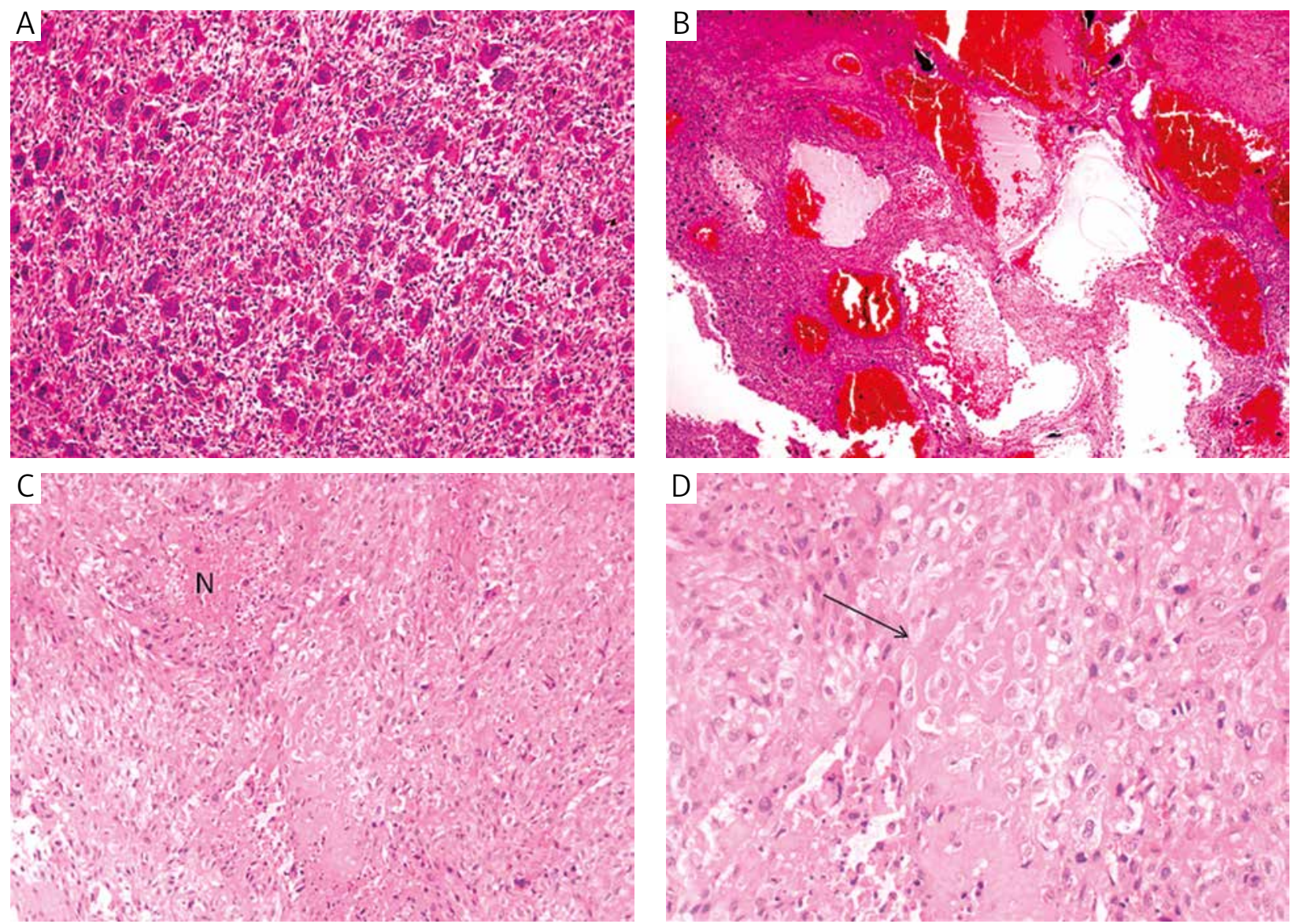

Fig. 3. A) Malignant transformation of the giant cell tumor in the sacrum in a 46-year-old woman. The primary tumor consists of fusiform stromal cells and scattered multinucleated osteoclast-like giant cells (HE, 200×). B) Aneurysmal bone cyst-like areas with vascular channels lined by osteoclastic giant cells (HE, 200×). C) Recurrent tumor in the same patient. Tumor consists of cellular proliferation of short spindle-shaped cells and an area of necrosis $(\mathrm{N})$ within the sarcomatous tumor cells (HE, $\times 200)$. D) The tumor contains osteoid production associated with anaplastic tumor cells $(\downarrow, \mathrm{HE}, \times 200)$ 
Table III. P values for the relation between recurrence and clinicopathological findings.

\begin{tabular}{|c|c|c|c|c|}
\hline & & \multicolumn{2}{|c|}{ RECURRENCE } & \multirow{2}{*}{$\mathbf{P}$} \\
\hline & & Negative $(\mathrm{N}=32)$ & $\operatorname{Positive~}(\mathrm{N}=10)$ & \\
\hline Gender & $\mathrm{M} / \mathrm{F}$ & $17(53) / 15(47)$ & $3(30) / 7(70)$ & 0.284 \\
\hline \multirow{2}{*}{ Tumor site } & Axial skeleton & $5(15.62)$ & $4(40)$ & \multirow{2}{*}{0.181} \\
\hline & Nonaxial skeleton & $27(84.38)$ & $6(60)$ & \\
\hline \multirow{2}{*}{ Sc. ABC } & Negative & $22(68.75)$ & $8(80)$ & \multirow{2}{*}{0.696} \\
\hline & Positive & $10(31.25)$ & $2(20)$ & \\
\hline \multirow{2}{*}{ Surgery } & Curettage & $18(56.25)$ & $7(70)$ & \multirow{2}{*}{0.490} \\
\hline & Resection & $14(43.75)$ & $3(30)$ & \\
\hline \multirow[t]{2}{*}{$\mathrm{p} 53$} & Negative & $20(62.50)$ & $2(20)$ & \multirow{2}{*}{$0.030 *$} \\
\hline & Positive & $12(37.50)$ & $8(80)$ & \\
\hline \multirow{2}{*}{$\mathrm{Ki}-67$} & Negative & $15(46.87)$ & $3(30)$ & \multirow{2}{*}{0.473} \\
\hline & Positive & $17(53.13)$ & $7(70)$ & \\
\hline \multirow{2}{*}{$\begin{array}{l}\text { Vascular } \\
\text { invasion }\end{array}$} & Negative & $29(90.62)$ & $9(90)$ & \multirow{2}{*}{1.000} \\
\hline & Positive & $3(9.38)$ & $1(10)$ & \\
\hline
\end{tabular}

M - Male; F-Female, Sc. ABC - Secondary aneurysmal bone cyst

* Statistically significant using Fisher's exact test $(p<0.05)$

\section{Discussion}

Many studies have reported on GCTB concerning the benign and yet aggressive behavior of the tumor and frequent recurrences if not adequately treated. Despite the use of Enneking's staging system and treatment plans, the recurrence rates are as high as $11.2-42 \%[4,5,6,7,14,15]$. Some reports indicated that $25 \%$ of the recurrences occurred within the first six-month period, $97 \%$ in the first couple of years, and $100 \%$ in the first three-year period $[16,17,18]$. In our series, the recurrence rate was $23.80 \%$, with eight cases $(80 \%)$ within the first two-year period. All recurrences were found within the first three-year period.

The definitive treatment for GCTB is surgery, including curettage, curettage and bone grafting, curettage and bone cementing, local use of phenol, formaldehyde or similar additional reagents, marginal excision and wide resection [2, 4, 14, 19]. Campanacci et al. suggested that the surgical margin is the most important prognostic factor, i.e. the presence of a tumor at the margin increases the recurrence rate [20]. This may explain the higher recurrence rates found in curettage and grafting patients. Some researchers reported that adjuvant agents may help to decrease the risk of recurrence $[14,19,21]$. Recurrent lesions are usually treated with a repeat curettage. The recommended wide resection in recurrences is sometimes not preferred, because it may lead to a loss of the joint adjacent to the tumor [18]. Local radiotherapy was recommended to control the local recurrences in the past, but was condemned due to the potential relationship between former radiotherapy and malignant transformation. However, radiotherapy is still used to treat tumors located in the vertebrae as a technically complete resection is not feasible [2]. Surgical treatment consists of curettage, curettage and grafting, curettage and bone cementing, and wide resection in our series. The highest recurrence rate was found in curettage and grafting, and curettage and bone cementing cases. The recurrence rates were lower in the wide resected cases. However, we did not find any statistical relationship between type of surgery and recurrence rate in our series. Local radiotherapy was used in three recurrent cases in the proximal femur, distal tibia, and clivus.

Although some studies support relationships between recurrence and cortical destruction, soft tissue invasion, the presence of pathological fractures, tumor size, early ages, gender, and tumor site, e.g. distal radius, proximal femur, axial skeleton, or small bone involvement, others have suggested that there are no relationships at all $[4,5,7,9,14,19,21,22]$. Cases involving the axial skeleton have been reported to have a particularly high recurrence rate [5]. Recurrence sites were the vertebrae $(n=3)$, phalanx $(n=2)$, clivus $(n=1)$, and proximal femur $(n=1)$ in our series and all were sites leading to inadequate surgical intervention.

In cases of young patients, specifically under 30 years, the recurrence rate was high. This may be due to a high bone turnover rate in the young [19]. The youngest patient with a recurrent tumor in our series was a 17 year-old female. Eight patients were between ages 20 and 40, and the oldest was 56 years old.

There is debate regarding the relationship between pathological fractures, soft tissue invasion and recur- 
rence $[4,19,21]$. In our series one of the two cases with pathological fractures had a recurrence in the phalanx.

Jiang et al. reported that the recurrence rate was higher in female patients in a study of 140 cases [6]. Similarly, in 7 of the 10 recurrent cases in our series the patients were female.

Lung metastases are very rare in GCTB, and occur in $1-6 \%$ of all cases. In such cases, the primary tumor site is usually the distal radius expressing locally aggressive behavior. Lung metastases are diagnosed within 3-4 years following initial diagnosis, and both genders are equally affected $[4,5,7,8,19]$. Moreover, some studies suggest that embolization of tumor cells during surgery for recurrent lesions underlies lung metastasis, whereas some studies suggest that there is no such relationship at all $[4,18,19,23]$. Interestingly, there are tumor thrombi in the vasculature peripheral to the tumor in one-third of the cases. However, this vascular invasion is not related to lung metastasis [4]. Lung metastases are more frequent in cases of recurrence $[10,11]$. Most studies assume that local recurrence of GCTB is a risk factor for lung metastasis [11]. Chung Ming Chan et al. reported that the risk of lung metastasis of GCTB appears to increase with younger age at presentation, axial location, local recurrence, and Enneking stage-3 primary tumor [10]. Limited reports suggest early surgical removal of lung metastases as the preferred mode of treatment. Neoadjuvant chemotherapy, bisphosphonates, interferon $\alpha$, and RANKL inhibitors are recommended as other treatment choices in such cases $[8,11,14,23]$. Denosumab is a novel drug that inhibits normal and tumor associated osteolysis by preventing the function of RANKL, and may be an effective alternative based on the fact that giant cell tumors overexpress RANKL and its receptor. In our series, two patients had lung metastasis at the time of initial diagnosis, and one patient had lung metastasis at the time of local recurrence. Four patients with vascular invasion did not have lung metastasis.

It is impossible to predict local aggressiveness and metastatic potential from the histological appearance of GCTB alone [1, 2]. Many studies have been performed to identify the prognostic markers in biopsies to predict clinical behavior. The Campanacci staging system, Ki-67 proliferative index, and $\mathrm{p} 53$ positivity are among the most popular prognostic markers $[9,16,24,25]$. Ki-67 is a nuclear protein found in proliferating cells. It is expressed in the active phases of the cell cycle, i.e., G1, S, G2, and M, as it is not found in the G0 phase. Thus, it is a perfect marker of proliferating cells in both normal and tumor tissue. Usually the Ki-67-positive fraction of cells is correlated with the course of the disease, as it not only indicates the portion of mitotic cells but also indicates the portion of all proliferating cells. The percentage of cells expressing cellular staining with the immuno- histochemical stain for $\mathrm{Ki}-67$ gives the proliferative index. The index is usually high in aggressive tumors and is regarded as a poor prognostic factor $[25,26$, 27]. In our series, giant cells were $\mathrm{Ki}-67$-negative in all cases and mononuclear cells were Ki-67-positive in various proportions of tumor cells. This finding suggests that mononuclear cells are responsible for the proliferative activity in GCTB. Furthermore, several studies report that the $\mathrm{Ki}-67$ index in recurrent cases is higher than in the primary tumor, and some studies report that there is no difference between the primary tumor and the recurrent tumor $[16,26,27\}$. Ismail et al. emphasized that $\mathrm{Ki}-67$ is not a useful immunopathological marker in predicting local recurrence and lung metastasis of GCTB [25]. We did not find a statistically significant relationship between the Ki-67 index and local recurrence and lung metastasis.

There is a small number of studies suggesting that p53 expression is an important prognostic marker in predicting local recurrence and lung metastasis [9, 16, 24]. Although originally responsible for tumor suppression, the mutant $\mathrm{p} 53$ gene can no longer suppress tumor growth, and furthermore, the mutant $\mathrm{p} 53$ protein promotes tumor growth and dissemination. The presence of mutant p53 protein is an indicator of tumor aggressiveness in various tumors. The $\mathrm{p} 53$ gene mutation has been rarely reported in GCTB $[12$, 13, 16, 28]. Papanastassiou et al. emphasized a correlation between the p53 mutation and local recurrence and tumor aggressiveness in GCTB [24]. In our series, a statistically significant relationship between p53 expression and local recurrence was revealed $(p=0.022)$. Of the cases with lung metastasis, weakly positive staining was found in cases with the primary tumor in the tibia and vertebra.

Malignant transformation in GCTB is rare (1.4$6.6 \%$ of all cases) and typically develops following multiple local recurrences. Most of the malignant GCTB evolve years after surgery and are associated with previous radiotherapy or occur de novo. On the other hand, cases of sarcomatous transformation in sites of GCTB following surgery alone have also been reported (so-called primary malignant GCTB) $[1,12$, $13,17,29,30]$. Usually the malignant transformation of the GCTB has the morphology of osteosarcoma, fibrosarcoma, or so-called malignant fibrous histiocytoma (secondary malignancy in GCTB) $[5,29]$. In most cases, the malignant transformation is diagnosed within five years following primary resection. Various oncogenes and tumor suppressor genes, including p 53 and $\mathrm{H}$-ras, are thought to affect this transformation $[12,13,17,30]$. Okubo et al. reported that p53 and high GPX-1 expression is of great help in diagnosing malignant transformation in GCTB [12]. Prognosis is poor in cases with malignant transformation, and the five-year survival rate is $0-50 \%$. A 46-year-old female patient with sacral GCTB in our series had os- 
teosarcomatous transformation three years following initial therapy. She did not have a history of radiotherapy. Unfortunately, she died seven months after wide resection and chemotherapy due to recurrence and multiple lung metastases. Immunohistochemistry revealed a weak positivity for p 53 in the primary GCTB and strong positivity for p53 in the recurrent malignant tumor. The $\mathrm{Ki}-67$ index was also low in the primary tumor and high in the recurrent tumor.

\section{Conclusions}

In conclusion, the only prognostic factor with a statistically significant relationship we could find was p53 expression. However, we provide evidence suggesting that primary sites, including the proximal femur, axial skeleton, and small bones, and female gender may increase the risk of recurrence, although the results were not statistically significant. We conclude that the prognosis of malignant GCTB is poor, and p53 expression may be helpful in predicting clinical behavior, including local recurrence. Further studies with a larger number of cases may result in a better understanding and more information regarding this matter.

The authors would like to thank American Journal Experts (www.aje.com) for the English language review.

The authors declare no conflict of interest.

\section{References}

1. Fletcher CDM, Bridge JA, Hogendoorn PCW, et al. World Health Organization Classification of Tumours of Soft Tissue and Bone. IARC, Lyon 2013; 321-324.

2. Folpe AL, Inwards CY. Bone and Soft Tissue Pathology. Saunders Elsevier, Philadelphia 2010; 401-407.

3. Jaffe HL, Linchenstein L, Portis R. Giant cell tumor of bone. Arch Pathol 1940; 30: 993-1031.

4. Alberghini M, Kliskey K, Krenacs T, et al. Morphological and immunophenotypic features of primary and metastatic giant cell tumour of bone. Virchows Arch 2010; 456: 97-103.

5. Gupta R, Seethalakshmi V, Jambhekar NA, et al. Clinicopathologic profile of 470 giant cell tumors of bone from a cancer hospital in western India. Ann Diagn Pathol 2008; 12: 239248.

6. Jiang $\mathrm{N}$, Qin $\mathrm{CH}$, Tan $\mathrm{CX}$, et al. A retrospective analysis of 140 patients with giant cell tumor in the extremity: A multicenter study based on four hospitals in South China. Cancer Epidemiol 2013; 37: 294-299.

7. Errani C, Ruggieri P, Asenzio MAN, et al. Giant cell tumor of the extremity: a review of 349 cases from a single institution. Cancer Treat Rev 2010; 36: 1-7.

8. Liu J, Yang H, Sun R, et al. Retrospective analysis of patients with rare-site and metastatic giant cell tumor. Chin J Cancer Res 2013; 25: 585-592.

9. Zang K, Zhou M, Chen H, et al. Expression of IMP3 and IGF2 in giant cell tumor of spine is associated with tumor recurrence and angiogenesis. Clin Transl Oncol 2015;17: 570-575.

10. Chan CM, Adler Z, Reith JD, et al. Risk factors for pulmonary metastases from giant cell tumor of bone. J Bone Joint Surg Am 2015; 97: 420-428.
11. Muheremu A, Niu X. Pulmonary metastasis of giant cell tumor of bones. World J Surg Oncol 2014; 12: 261.

12. Okubo T, Saito T, Mitomi H, et al. p 53 mutations may be involved in malignant transformation of giant cell tumor of bone through interaction with GPX1. Virchows Arch 2013; 463: 67-77.

13. Oda Y, Sakamoto A, Saito T, et al. Secondary malignant giant-cell tumour of bone: molecular abnormalities of $p 53$ and $H$-ras gene correlated with malignant transformation. Histopathology 2001; 39: 629-637.

14. Balke M, Schremper L, Gebert C, et al. Giant cell tumor of bone: treatment and outcome of 214 cases. J Cancer Res Clin Oncol 2008; 134: 969-978.

15. Enneking WF. A system of staging musculoskeletal neoplasms. Clin Orthop Relat Res 1985; 204: 9-36.

16. Saito T, Mitomi H, Suehara Y, et al. A case of de novo secondary malignant giant-cell tumor of bone with loss of heterozygosity of $p 53$ gene that transformed within a short-term follow-up. Pathol Res Pract 2011; 207: 664-669.

17. Saito T, Mitomi H, Izumi H, et al. A case of secondary malignant giant-cell tumor of bone with $p 53$ mutation after longterm follow-up. Hum Pathol 2011; 42: 727-733.

18. Balke M, Ahrens H, Streitbuerger A, et al. Treatment options for recurrent giant cell tumors of bone. J Cancer Res Clin Oncol 2009; 135: 149-158

19. Klenke FM, Wenger DE, Inwards CY, et al. Giant cell tumor of bone. Clin Orthop Relat Res 2011; 469: 591-599.

20. Campanacci M, Baldini N, Boriani S, et al. Giant cell tumor of bone. J Bone Joint Surg Am 1987; 69: 106-114.

21. Heijden L, Sande MA, Dijkstra PD. Soft tissue extension increases the risk of local recurrence after curettage with adjuvants for giant-cell tumor of the long bones, A retrospective study of 93 patients. Acta Orthop 2012; 83: 401-405.

22. Yanagisawa M, Okada K, Tajino T, et al. A clinicopathological study of giant cell tumor of small bones. Ups J Med Sci 2011; 116: $265-268$

23. Miller IJ, Blank A, Yin SM, et al. A case of recurrent giant cell tumor of bone with malignant transformation and benign pulmonary metastases. Diagn Pathol 2010; 5: 62-68.

24. Papanastassiou I, Ioannou M, Papagelopoulos PJ, et al. p53 expression as a prognostic marker in giant cell tumor of bone: a pilot study. Orthopedics 2010; 33: 307.

25. Ismail FW, Shamsudin AM, Wan Z, et al. Ki-67 immuno-histochemistry index in stage III giant cell tumor of the bone. J Exp Clin Cancer Res 2010; 29: 25.

26. Rousseau MA, Luca AH, Lazennec JY, et al. Metachronous multicentric giant-cell tumor of the bone in the lower limb. Case report and Ki-67 immunohistochemistry study. Virchows Arch 2004; 445: 79-82.

27. Kauzman A, Li SQ, Bradley G, et al. Cyclin alterations in giant cell tumor of bone. Mod Pathol 2003; 16: 210-218.

28. Wu Y, Hsiu J, Lou Y, et al. $\mathrm{p} 53$ protein accumulation and genetic alterations in human giant cell tumors of bone (osteoclastomas). Int J Oncol 1997; 10: 1087-1092.

29. Bertoni F, Bacchini P, Staals EL. Malignancy in giant cell tumor of bone. Cancer 2003; 97: 2520-2529.

30. Gong L, Liu W, Sun X, et al. Histological and clinical characteristics of malignant giant cell tumor of bone. Virchows Arch 2012; 460: 327-334

\section{Address for correspondence}

\section{Ulviye Yalcinkaya}

Uludag University Medical School

Department of Surgical Pathology, Gorukle

16059 Bursa, Turkey

e-mail: drulviyeyalcinkaya@gmail.com 